\title{
The influence of cruise ship emissions on air pollution in Svalbard - a harbinger of a more polluted Arctic?
}

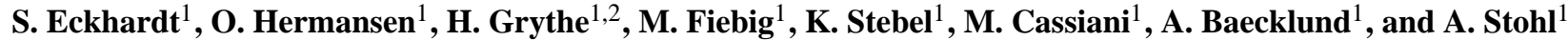 \\ ${ }^{1}$ NILU - Norwegian Institute for Air Research, Kjeller, Norway \\ ${ }^{2}$ Department of Applied Environmental Science (ITM), Stockholm University, Stockholm, Sweden
}

Correspondence to: S. Eckhardt (sec@nilu.no)

Received: 21 December 2012 - Published in Atmos. Chem. Phys. Discuss.: 30 January 2013

Revised: 28 June 2013 - Accepted: 7 July 2013 - Published: 26 August 2013

\begin{abstract}
In this study we have analyzed whether tourist cruise ships have an influence on measured sulfur dioxide $\left(\mathrm{SO}_{2}\right)$, ozone $\left(\mathrm{O}_{3}\right)$, Aitken mode particle and equivalent black carbon (EBC) concentrations at Ny Ålesund and Zeppelin Mountain on Svalbard in the Norwegian Arctic during summer. We separated the measurement data set into periods when ships were present and periods when ships were not present in the Kongsfjord area, according to a long-term record of the number of passengers visiting Ny Ålesund. We show that when ships with more than 50 passengers cruise in the Kongsfjord, measured daytime mean concentrations of $60 \mathrm{~nm}$ particles and EBC in summer show enhancements of 72 and $45 \%$, respectively, relative to values when ships are not present. Even larger enhancements of 81 and $72 \%$ were found for stagnant conditions. In contrast, $\mathrm{O}_{3}$ concentrations were $5 \%$ lower on average and $7 \%$ lower under stagnant conditions, due to titration of $\mathrm{O}_{3}$ with the emitted nitric oxide (NO). The differences between the two data subsets are largest for the highest measured percentiles, while relatively small differences were found for the median concentrations, indicating that ship plumes are sampled relatively infrequently even when ships are present although they carry high pollutant concentrations. We estimate that the ships increased the total summer mean concentrations of $\mathrm{SO}_{2}, 60 \mathrm{~nm}$ particles and EBC by 15, 18 and $11 \%$, respectively. Our findings have two important implications. Firstly, even at such a remote Arctic observatory as Zeppelin, the measurements can be influenced by tourist ship emissions. Careful data screening is recommended before summertime Zeppelin data is used for data analysis or for comparison with global chemistry transport models. However, Zeppelin remains as one of the most valuable Arctic observatories, as most other Arctic
\end{abstract}

observatories face even larger local pollution problems. Secondly, given landing statistics of tourist ships on Svalbard, it is suspected that large parts of the Svalbard archipelago are affected by cruise ship emissions. Thus, our results may be taken as a warning signal of future pan-Arctic conditions if Arctic shipping becomes more frequent and emission regulations are not strict enough.

\section{Introduction}

Ship traffic is a substantial source of pollution globally, and it is of particular concern in regions with heavy ship traffic (e.g., near ports or major shipping lanes) or where few other pollution sources exist, such as the high-latitude regions. It has been found that shipping-related particulate matter emission have a significant influence on cardiopulmonary and lung cancer deaths (Corbett et al., 2007). Although the Arctic population is low, shipping emissions will also contribute to health concerns. Norwegian coastal ship traffic, for instance, is responsible for more than $1 / 3$ and $1 / 6$ of the Norwegian emissions of nitrogen oxides $\left(\mathrm{NO}_{\mathrm{x}}\right)$ and sulfur dioxide $\left(\mathrm{SO}_{2}\right)$, respectively, and contributes substantially to coastal pollution (Dalsøren et al., 2007). While shipping in the high Arctic is currently limited by sea ice, observations in the Arctic boundary layer suggest that shipping around the periphery of the Arctic Ocean is an important source of black carbon (BC - we use $\mathrm{BC}$ as a qualitative term for material that (1) has a high fraction of sp2-bonded carbon, (2) consists of aggregates of carbon spherules, (3) is thermally refractory up to $4000 \mathrm{~K}$, (4) is hydrophobic, and (5) is strongly broadband absorbing for visible light) and polycyclic aromatic 
hydrocarbons (Xie et al., 2007). Arctic ship emissions also contribute to the radiative forcing of the climate system and may be important for regional climate change (Ødemark et al., 2012).

Oil and gas extraction in the Arctic is expected to increase in the future and this will require corresponding increases of shipping activity (Peters et al., 2011). Furthermore, diminishing summer sea ice due to climate warming is likely to prompt a substantial number of cargo ships to take the shorter passages through the Arctic instead of using their current routes. This could lead to large increases of ship emissions in the Arctic (Corbett et al., 2010). More realistic scenarios for the year 2030 lead to smaller changes in ozone but maintain larger than $50 \%$ increases of BC concentrations, unless BC emission reduction measures are implemented (Dalsøren et al., 2013). It has been estimated that ship emission of ozone precursors could lead to a $10 \%$ increase in ozone in the Arctic lower troposphere (Dalsøren et al., 2013).

One particular type of Arctic ship activity has already increased substantially during the last two decades, namely sightseeing cruises. Major touristic destinations in the polar regions are the Antarctic Peninsula, Greenland and Svalbard (Spitsbergen), and concern is rising that cruise ship emissions affect the pristine polar atmospheres and fragile ecosystems. For instance, Graf et al. (2010) found that tourist ships are the largest local source of $\mathrm{SO}_{2}$ and $\mathrm{BC}$ in the Antarctic and entirely dominate $\mathrm{SO}_{2}$ and $\mathrm{BC}$ emissions near the Antarctic Peninsula. They also reported a $43 \%$ increase in the number of tourist ships visiting Antarctica over the short period from 2004/2005 to 2007/2008. Similar increases have been reported for the Arctic. The annual number of tourists landing on Svalbard increased from 40000 at the end of the 1990s to 100000 during the period 2006-2010 (Hagen et al., 2012). According to the emission inventory of Vestreng et al. (2009), $93 \%$ of the $\mathrm{BC}$ and $90 \%$ of the $\mathrm{NO}_{\mathrm{x}}$ emissions in the Svalbard archipelago $\left(10-35^{\circ} \mathrm{E}, 74-81^{\circ} \mathrm{N}\right)$ in the year 2007 were due to marine transport (primarily cruise ships and coal transportation), while land-based emissions accounted for less than $10 \%$. Furthermore, most of the emission increase from 2000 to 2007 (BC: $56 \%, \mathrm{NO}_{\mathrm{x}}: 54 \%$ ) was due to cruise ships. The emission inventory (Vestreng et al., 2009) is likely to be conservative as the $\mathrm{BC}$ emission factors used are probably too low for Arctic conditions (Lack and Corbett, 2012).

In this study, we investigate the influence of ship plumes on the measurements of $\mathrm{SO}_{2}, \mathrm{O}_{3}$, Aitken mode particle and equivalent BC (EBC) concentrations in the Svalbard village of Ny Alesund and at the nearby Arctic background monitoring station at Zeppelin Mountain. This area is influenced by tourist ships cruising in the Kongsfjord and anchoring at Ny Ålesund. Weinbruch et al. (2012) analyzed aerosol samples taken at Zeppelin during a measurement campaign with electron microscopy and suggested that soot (characterized by its fractal-like morphology) was only observed when cruise ships were present in the Kongsfjord. According to Elefthe- riadis et al. (2009), $0.2 \%$ of the measured EBC values at Zeppelin appear to be influenced by local pollution, probably from ships. However, to date no systematic long-term study on the influence of ship emissions on measurements at Zeppelin has been published. The purpose of this study is to quantify this influence.

\section{Methods}

\subsection{Study area and some meteorological considerations}

The region of our study is shown in Fig. 1. Sightseeing ships with typically a few hundred but up to 3000 tourists often cruise in the Kongsfjord and anchor in the village of Ny Alesund $\left(11.93^{\circ} \mathrm{E}, 78.92^{\circ} \mathrm{N}\right)$. Research and supply vessels visit Ny Ålesund as well. The village is a permanent settlement (population in winter around 35, more in summer) with a number of international research stations. There is a small power station for electric power generation, but energy demands in summer are modest and power plant emissions are low compared to ship emissions (Vestreng et al., 2009). In this paper, we present measurement data collected at a temporary station in the "center" of the village (red dot in Fig. 1) and at the permanent research station Zeppelin, which is located approximately $2 \mathrm{~km}$ away from Ny Alesund at an altitude of $472 \mathrm{~m}$ (blue dot in Fig. 1). The station is situated in an unperturbed Arctic environment on a ridge of Zeppelin Mountain and is accessible to researchers by a cable car.

The meteorological conditions in the study area are complex, due to the mountain ranges on both sides of the fjord (Fig. 1) and the temperature contrasts between sea and land. Winds are channeled inside the fjord and surface wind measurements at Ny Ålesund and Zeppelin are not representative of general wind conditions in the area. Likewise, boundarylayer heights and thus vertical mixing are highly variable (Vihma et al., 2011). The Zeppelin station is often above a temperature inversion layer but can also be located within the boundary layer (Tunved et al., 2013; Di Liberto et al., 2012). Pollution plumes are rare at Zeppelin (Eleftheriadis et al., 2009) because of the low emissions in the village, the distance to the station and the limited vertical mixing. However, smoke stacks of large ships are elevated emission sources and their buoyant exhaust can rise substantially.

To identify the influence of ship emissions on aerosol and air chemistry measurement data, we used a very simple approach: we binned the data according to ship presence in the fjord (see Sect. 2.2). A more specific approach of quantifying ship plume influence was not possible since the combination of moving sources and the complex local meteorology made predictions of exhaust transport to the stations difficult. The lack of specificity of our criteria implied that clean conditions can be expected at the stations most of the time even when ships were in the fjord, but pollution events were expected 


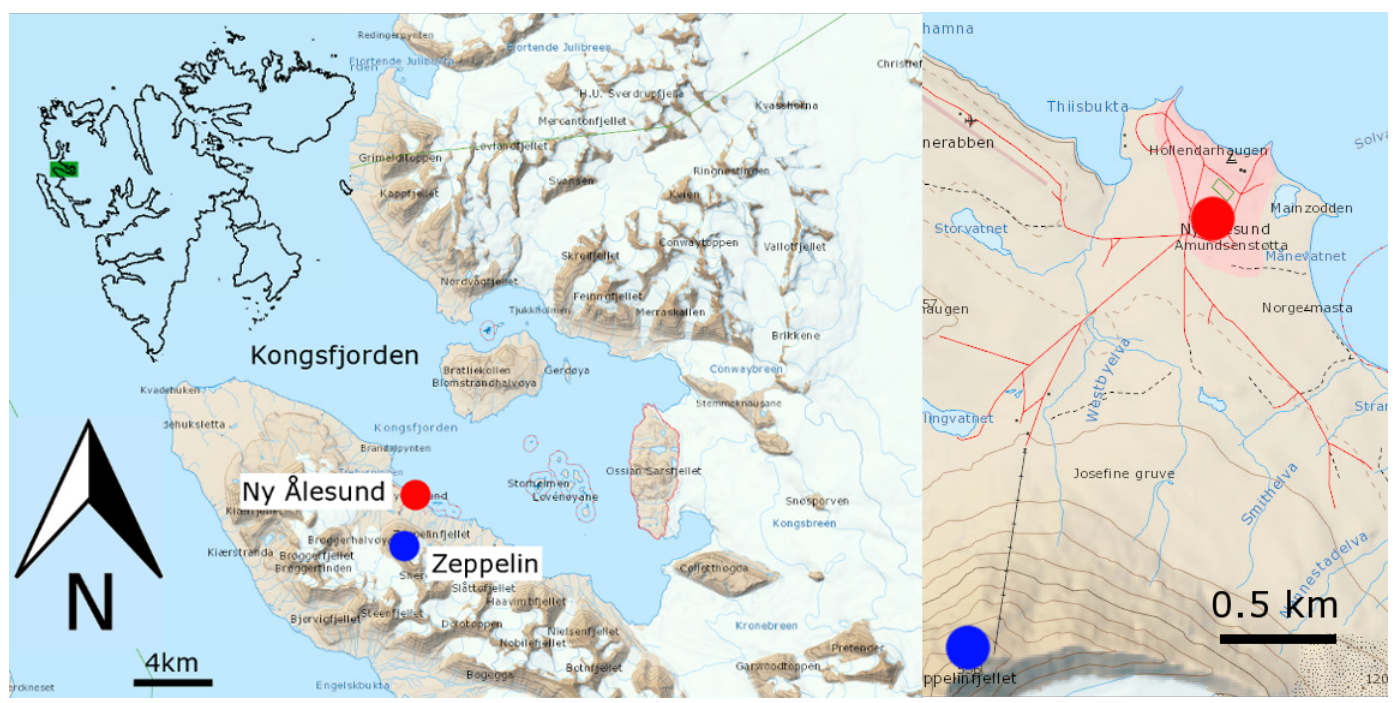

Fig. 1. Left panel: map of the Kongsfjord area of Svalbard, showing the locations of the village of Ny Ålesund (red dot) and the Zeppelin Mountain station (blue dot). The inset in the upper left corner shows the coastlines of Svalbard, the green rectangle indicating the approximate extent of the map. Right panel: detailed map of the Ny Ålesund area, with the red dot showing the position of the Ny Ålesund monitoring station, and the blue dot showing the position of the Zeppelin Mountain station. (Courtesy of Norwegian Polar Institute, http://toposvalbard. npolar.no/).

to be much more frequent under these conditions than when ships are not present.

\subsection{Ship presence in the Kongsfjord}

The harbor master of Kings Bay AS company keeps detailed hourly records about when ships arrive and leave the dock or anchor position, as well as on the number of people visiting the island (H. Gisnås, personal communication, 2012). This record is generally of high quality, but it is known that occasionally ships are not registered. Figure 2 shows the total number of passengers visiting Ny Ålesund between the years 2000 and 2011. Between the years 2000 and 2007, tourist numbers have more than doubled, while since then there has not been a clear trend in the number of passengers. A similar trend has been reported by Hagen et al. (2012) for the entire Svalbard archipelago, where a total of about 200 ship landing sites have been used in recent years. According to data in Fig. 1 and in Hagen et al. (2012), Ny Ålesund accounts for around $15 \%$ of all Svalbard ship landings.

Ship names are not recorded in a systematic enough way to clearly identify each vessel, which would allow estimation of its pollutant emissions. Therefore, we use the number of passengers as a proxy for the size of a ship and the corresponding pollutant emissions. The correlation between the number of passengers and a ship's emissions is probably weak and, therefore, we separate all data in only two classes: (1) when no ship was present in the fjord (case "no ships"), and (2) when ship(s) with a total of more than 50 passengers were present (case "ships"). However, 500 passengers were used as a threshold for $24 \mathrm{~h}$ samples of $\mathrm{SO}_{2}$ (see Sect. 1.4).
This means we counted the total number of passengers disembarking during the $24 \mathrm{~h}$ period, as most ships are not in the harbor for all of the $24 \mathrm{~h}$. To be consistent with the hourly measurements, we used a threshold for this total number of 500 passengers.

Tourist ships typically cruise in the Kongsfjord for a few hours before or after visiting Ny Ålesund, and it also takes some time to reach or leave Ny Ålesund from outside the Kongsfjord. Pollutant emissions are also likely to be higher when the ships cruise in the fjord than when they are anchored. However, no information is available about the duration of the Kongsfjord cruises and the exact routes the ships take. We therefore consider ships to be in the Kongsfjord from the registered arrival time until $4 \mathrm{~h}$ after the registered departure time from Ny Ålesund. This also leaves some margin for the presence of pollution and transport to the Zeppelin station after a ship has left the fjord. When considering measurements in Ny Ålesund, only a $2 \mathrm{~h}$ extension was used because the strongest influence there is expected when ships are at anchor. Although these time margins are somewhat arbitrary, they do not matter for quantifying the total ship influence as long as they cover the periods with potential ship presence.

Tourists visit Ny Ålesund mainly during the months from June to August, so only this period is considered in our study. Ships normally arrive during daytime and leave before the evening, so we restrict most of our analysis to daytime hours from 08:00 to 20:00 local time (06:00 to 18:00 UTC). 

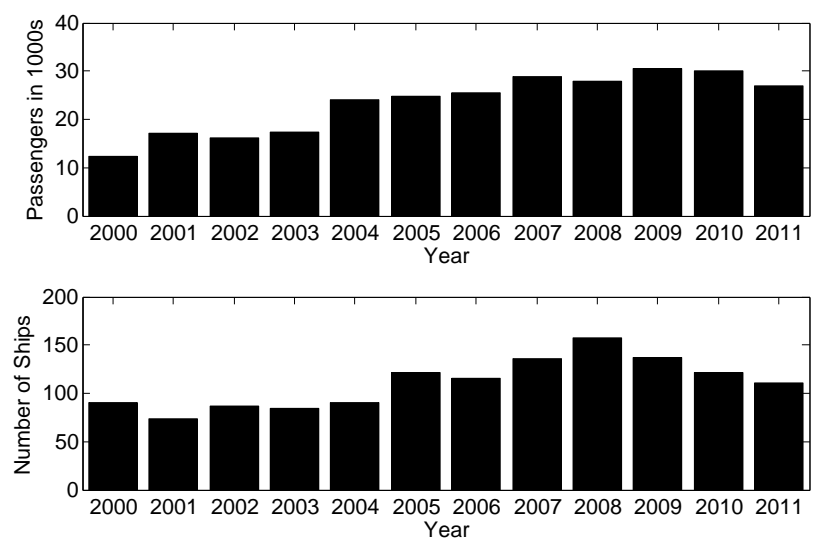

Fig. 2. Total number of ship passengers visiting Ny Ålesund per year (upper panel) and number of ships registered in the Ny Ålesund harbor log (lower panel).

\subsection{Measurements in Ny Ålesund}

From July 2008 to August 2010, a measurement campaign was carried out to investigate the impact of local pollution sources on air quality in Ny Ålesund. For this purpose a monitoring station was set up in the "center" of Ny Ålesund where carbon monoxide, $\mathrm{SO}_{2}, \mathrm{NO}_{\mathrm{x}}$ and $\mathrm{EBC}$ measurements were carried out with a sampling time of 1-5 min. However, $\mathrm{BC}$ data were not available, so for this study only hourly $\mathrm{SO}_{2}$ averages were used, since of the remaining compounds $\mathrm{SO}_{2}$ is the most specific indicator of ship emissions. $\mathrm{SO}_{2}$ was measured using a Teledyne API 100E UV fluorescence $\mathrm{SO}_{2}$ analyzer. High instrumental stability was achieved with the use of an optical shutter to compensate for photomultiplier drift and a reference detector to correct for changes in UV lamp intensity. A hydrocarbon "kicker" and advanced optical design were combined to prevent inaccuracies due to interferents. The instrument is usually used for monitoring higher concentrations than the background conditions in Ny Ålesund, so the concentrations measured during the campaign were below the detection limit most of the time. However, there were weekly tests on blank values which were used to remove a drift in the data. Therefore, while mean concentrations may be highly uncertain, the enhanced $\mathrm{SO}_{2}$ concentrations in ship plumes can be quantified.

\subsection{Equivalent $\mathrm{BC}$, particle size distribution, $\mathrm{SO}_{2}$ and $\mathrm{O}_{3}$ measurements at Zeppelin}

Monitoring of light-absorbing particles at Zeppelin has been performed since the year 2002 with a custom-built particle soot absorption photometer. In this instrument, light at $530 \mathrm{~nm}$ wavelength illuminates two $3 \mathrm{~mm}$ diameter spots on a single filter substrate, on one of which particles are collected from ambient air flushed through the filter, and the other kept clean as a reference (Bond et al., 1999). The change in light transmittance across the filter is measured to derive the particle light absorption coefficient $\sigma_{\mathrm{ap}}$, corrected for the influence of scattering particles. Conversion of $\sigma_{\mathrm{ap}}$ to $\mathrm{BC}$ concentrations requires the assumptions that all the light absorption measured is from $\mathrm{BC}$, and that all $\mathrm{BC}$ has the same light absorption efficiency. We convert $\sigma_{\mathrm{ap}}$ values to EBC mass concentrations using a value of $10 \mathrm{~m}^{2} \mathrm{~g}^{-1}$, typical of aged BC aerosol (Bond and Bergstrom, 2006). We are aware that there are uncertainties in the EBC data, which are related to the conversion, the sampling statistics and scattering correction (Bond et al., 1999); as most analyses are of comparative nature, systematic errors are expected to cancel out.

The particle size distributions were measured using a differential mobility particle sizer (DMPS) consisting of a Hauke differential mobility analyzer (Knutson and Whitby, 1975) and a TSI 3010 particle counter (detailed description in Tunved et al., 2013). The sheath flow is a closed-loop system (Jokinen and Makela, 1997). DMPS data from Zeppelin have been presented previously (Stroem et al., 2003) and cover the size range from 13.5 to $700 \mathrm{~nm}$ diameter (bin limits). For this study we only use the size bin which includes the $60 \mathrm{~nm}$ diameter (referred to as PN60), because it represents a typical size of relatively fresh ship exhaust. Over the years (20032010) different size bins were used. From 2003 to 2007 the mean value of the size bin used is $63.5 \mathrm{~nm}$; from 2008 to $200963.1 \mathrm{~nm}$ and in $201059.7 \mathrm{~nm}$.

$\mathrm{SO}_{2}$ was sampled with the three-stage filter pack method, which is the reference method in the European Monitoring and Evaluation Program (EMEP/CCC, 2001; Aas et al., 2007). $\mathrm{SO}_{2}$ was absorbed on a potassium-hydroxideimpregnated Whatman 40 filter, extracted in the laboratory with a hydrogen peroxide solution and analyzed with an ion chromatograph. The sampling duration was $24 \mathrm{~h}$, so only full days with/without ship presence were distinguished for $\mathrm{SO}_{2}$.

$\mathrm{O}_{3}$ was measured with an UV-absorption instrument API400A with a lower detection limit of $0.6 \mathrm{ppbV}$. Zero-span checks were done every second week to compensate for zero drift, and a manual calibration was done once a year using a TEI 49 CPS \#60955-329 as a reference. The air intake is through a $4.5 \mathrm{~m}$ FEP tube with an outer diameter of $6.35 \mathrm{~mm}$ and an inner diameter of $4.75 \mathrm{~mm}$.

\section{Case study}

On 1 July 2009, the cruise ship Vistamar with 281 passengers on board arrived in the harbor at 07:30 (05:30 UTC). and departed at 10:30 (08:30 UTC). At 10:30 (08:30 UTC), another ship, Athena, with 377 passengers arrived and stayed until 15:30. In addition, smaller ships also arrived during the afternoon (Albarquel, 9; Quest, 53; and in the evening an expedition with 73 people). Total passenger numbers as a function of time of day are shown in Fig. 3b (black line). During this day, the wind speeds measured at Zeppelin were only around 

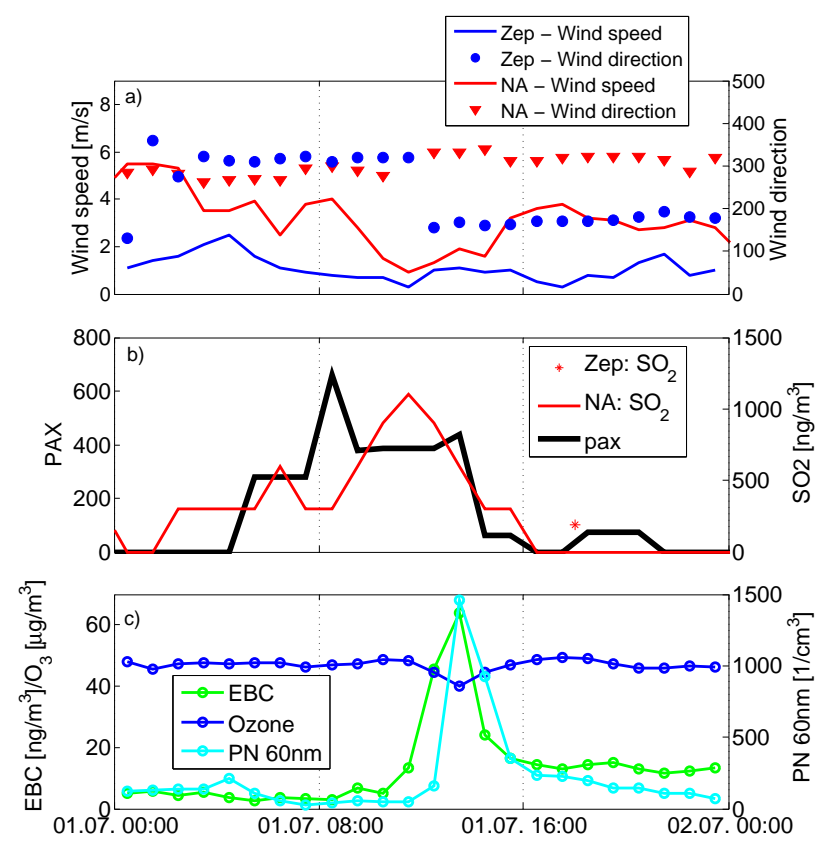

Fig. 3. Wind and air chemistry measurements at Zeppelin and in $\mathrm{Ny}$ Ålesund during 1st July 2009. The top panel (a) shows hourly measurements of wind speed $\left(\mathrm{m} \mathrm{s}^{-1}\right)$ and wind direction at Zeppelin (blue) and in Ny Ålesund (red). In the middle panel (b), the black line indicates the number of passengers in the harbor (PAX), the red line shows the continuous $\mathrm{SO}_{2}$ measurements in $\mathrm{Ny}$ Allesund, and the red asterisk shows the daily average $\mathrm{SO}_{2}$ concentration at Zeppelin from filter sample measurements. In the lower panel (c), the green line is the EBC concentration, the light blue line the PN60 concentration, and the dark blue line shows the ozone concentration, all measured at Zeppelin.

$1 \mathrm{~m} \mathrm{~s}^{-1}$ with first northwesterly and then southerly directions. The low wind speeds led to accumulation of pollution in the fjord. The $\mathrm{SO}_{2}$ measurements in $\mathrm{Ny}$ Ålesund showed a first peak in $\mathrm{SO}_{2}$ of $0.6 \mu \mathrm{g} \mathrm{m}^{-3}$ when Vistamar arrived and a more pronounced maximum of $1.1 \mu \mathrm{g} \mathrm{m}^{-3}$ when Athena was in the harbor (and Vistamar probably still cruising in the fjord). Two peaks could also be identified in the $\mathrm{NO}_{\mathrm{x}}$ measurements at Ny Ålesund (not shown), both associated with the $2 \mathrm{nd} \mathrm{SO}_{2}$ peak. The hourly average peak (daytime mean) $\mathrm{SO}_{2}$ concentrations of of $1.1 \mu \mathrm{g} \mathrm{m}^{-3}\left(0.46 \mu \mathrm{g} \mathrm{m}^{-3}\right)$ can be compared to the average summertime daily maximum (daytime mean) $\mathrm{SO}_{2}$ concentrations of $1.0 \mu \mathrm{g} \mathrm{m}^{-3}\left(0.3 \mu \mathrm{g} \mathrm{m}^{-3}\right)$, respectively. The hourly peak value is around the 90th percentile for summer daytime concentrations.

At Zeppelin, the maximum hourly EBC concentration was $64.1 \mathrm{ng} \mathrm{m}^{-3}$, which is above the 95th percentile of all summer daytime values. The PN60 concentration was $1461 \mathrm{~cm}^{-3}$, also above the 95th percentile. Even the $24 \mathrm{~h}$ mean $\mathrm{SO}_{2}$ value from the filter measurements of $0.19 \mu \mathrm{g} \mathrm{m}^{-3}$ was above the 95 th percentile of all summer values. For the time period of the peak EBC concentrations at Zeppelin, we also analyzed the aerosol size distribution and found that it had a similar shape to size distributions typical of ship emissions as determined in a laboratory study (Petzold et al., 2008). This provides strong evidence that the enhanced EBC concentrations in this case were indeed due to ship emissions. At the same time as EBC and Aitken mode particles peak, $\mathrm{O}_{3}$ shows a concentration dip, which can be explained by titration of $\mathrm{O}_{3}$ with nitric oxide (NO) emitted by the ships.

\section{Statistical analysis}

For the statistical analysis, we group all measurement data according to ship presence into two classes: "no ships" and "ships". For these groups, the $\mathrm{SO}_{2}$ concentrations in Ny Ålesund, and the $\mathrm{O}_{3}, \mathrm{EBC}$ and PN60 concentrations at Zeppelin are shown in box and whiskers plots (Fig. 4). There is a strong decreasing trend of the summer mean EBC concentrations at Zeppelin between 2003 and 2005. The 2006-2011 summer mean concentrations are then only about $1 / 3$ of the values measured during 2003 to 2005 . The reasons for this decrease are not entirely clear, although emission reductions in Eurasian source areas may play a role (Hirdman et al., 2010b). To reduce the impact of this trend on our analysis, we consider two separate periods, 2003-2005 and 2006-2011, for EBC.

For $\mathrm{SO}_{2}$ in $\mathrm{Ny}$ Alesund, the mean concentrations are $0.28 \mu \mathrm{gm}^{-3}$ for the group "no ships" and $0.40 \mu \mathrm{gm}^{-3}$ for "ships". According to a $t$ test, the means are statistically significantly different. As expected, the medians for both groups are similar, as ship plumes do not reach the station all the time even when ships are present. Similarly, at Zeppelin the mean EBC concentrations when ships are not present (for the first/second period) are $16.9 / 7.0 \mathrm{ng} \mathrm{m}^{-3}$ and when ships are present they are $24.7 / 10.0 \mathrm{ng} \mathrm{m}^{-3}$. Also the 75 th and 95 th percentile concentrations are consistently enhanced when ships are present, for both periods considered. A corresponding result is obtained for PN60, for which the mean concentration is also significantly higher for periods with ship presence $\left(298 \mathrm{~cm}^{-3}\right)$ than without $\left(173 \mathrm{~cm}^{-3}\right)$. In contrast, for $\mathrm{O}_{3}$, the mean concentrations are $2.8 \mu \mathrm{g} \mathrm{m}^{-3}$ lower when ships are present than when ships are not present. As for the case study, we attribute this to titration of $\mathrm{O}_{3}$ by $\mathrm{NO}$ in the ship plumes.

We repeated the above analysis but considering only low wind speed conditions. In this case, the differences between the two classes were even larger. For instance, the mean PN60 at Zeppelin during the period 2003-2010 was $81 \%$ higher when ships were present than when ships were not present. This shows that ship influence is enhanced under low wind speed conditions, as expected.

Our data show a statistically significant difference between periods when ships are present compared to times when ships are not present. However, most ships arrive during the daytime and pollutant concentrations generally are also highest 

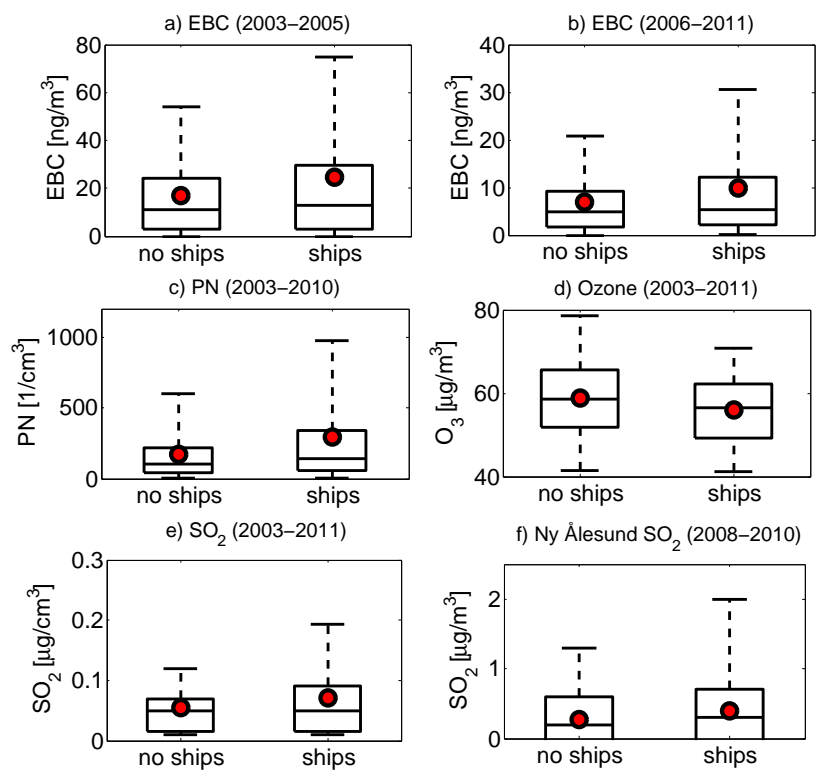

Fig. 4. Box and whisker plots of $\operatorname{EBC}(\mathbf{a}, \mathbf{b})$, particle number concentration for particles in the $60 \mathrm{~nm}$ size bin (c), ozone (d), $\mathrm{SO}_{2}$ at Zeppelin (e), and $\mathrm{SO}_{2}$ at $\mathrm{Ny}$ Alesund (f), for the two periods when ships are present in the harbor, or not. In the title of each panel the years used for the analysis are reported. The boxes extend from the 25th to the 75th percentile, the whiskers show the 5th and 95th percentile, and the thick red dots are the mean values. Data shown are for summer (June, July, August) daytime (06:00-18:00 UTC).

during daytime. To support our interpretation that the ship emissions cause the elevated pollutant levels and reject the alternative interpretation that ship presence and daily cycle of pollution are coincidentally correlated due to similar but unrelated daily cycles, we repeated our analysis shown in Fig. 4, but for every hour of the day separately.

Figure 5 shows that the EBC and PN60 concentrations are higher in the afternoon than in the morning, regardless of ship presence. They are consistently higher throughout the day when ships are present, with very few exceptions, notably in the early morning hours, when ships only start arriving and the number of "ships" cases is very low. The $\mathrm{O}_{3}$ concentrations are consistently lower throughout the day when ships are present.

While it is interesting to compare pollution levels for periods with and without ship influence, the overall influence of ship emissions on the seasonal mean concentrations depends also on the frequency and duration of the periods with ship presence. To determine the overall effect of ship emissions on the mean measured pollutant concentrations in Ny Ålesund and at Zeppelin taking into account the different frequency of periods with or without ships, we compare the mean concentration, averaged over all "no ships" periods ("background"), with the total mean concentration, averaged over the entire time. This was done for summer (June, July, August) during daytime only, for summer also including night-time peri-
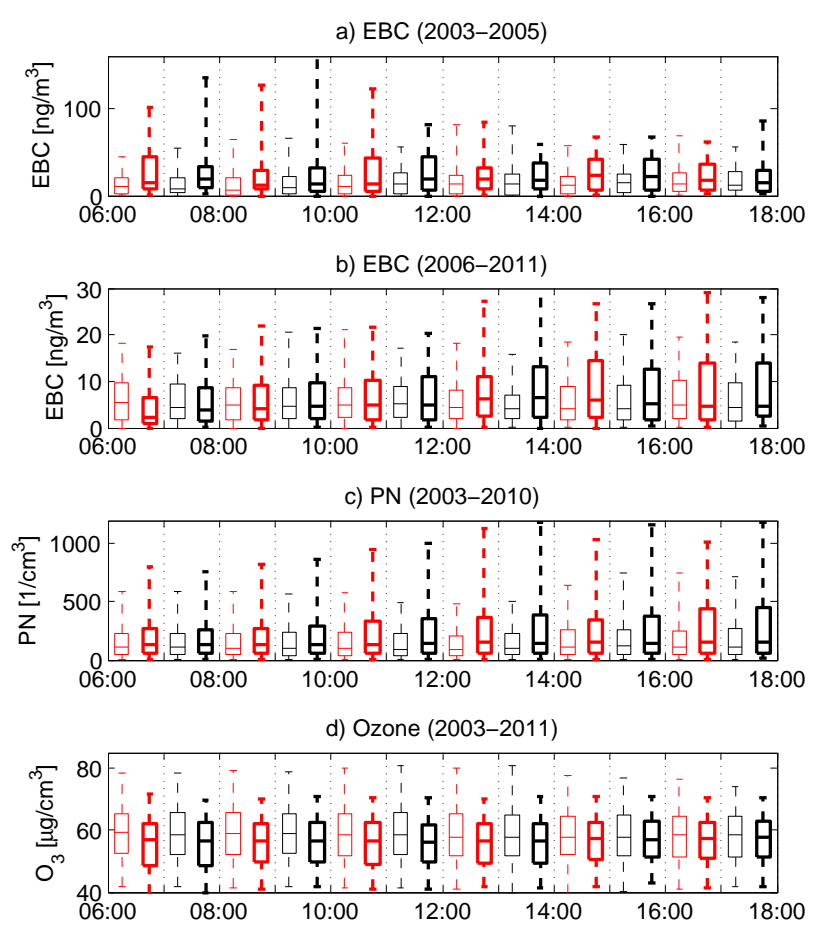

Fig. 5. Box and whisker plots of EBC, particle number concentration for the $60 \mathrm{~nm}$ size bin, and ozone measured at Zeppelin for each hourly interval between 06:00 a.m. and 06:00 p.m. UTC for the two categories describing whether ships are present in the harbor, or not. The boxes with the thin lines show the data when there are no ships; the boxes with the thick lines the data when there are ships. For clarity of presentation, the colors alternate every hour. Data shown are for summer (June, July, August) during the years given in each panel title.

ods, and for summer during daytime and with low-wind conditions only (Table 1). As can be expected, the relative increases in the total mean concentrations over the background mean concentrations are largest during daytime and for lowwind conditions. For this period, the relative ship-related increases over the background for EBC are 24/30\%, and for PN60 $31 \%$. There are still substantial increases in the mean concentrations due to ships for all wind conditions (12/23\% and $32 \%$ ), and even when including the night-time periods as well (8/11\% and $18 \%)$. Mean $\mathrm{SO}_{2}$ concentrations are also enhanced by the ship emissions, while $\mathrm{O}_{3}$ concentrations are decreased by $2-4 \%$. However, the influence of the ships on annual mean concentrations is minimal (not shown), since $\mathrm{SO}_{2}$ and $\mathrm{EBC}$ concentrations during the Arctic haze season (winter and early spring) are much higher than in summer, and ship influence is small during that period. In the Arctic, local pollution sources are very limited and most of the pollution observed near the surface is due to long-range transport from mid-latitude emission sources (traffic, industry, biomass burning, etc.), primarily located in high-latitude Eurasia (Stohl, 2006). 
Table 1. Mean EBC $\left[\mathrm{ng} \mathrm{m}^{-3}\right]$, PN60 $\left[1 \mathrm{~cm}^{-3}\right]$, ozone $\left[\mu \mathrm{g} \mathrm{m}^{-3}\right.$ ] at Zeppelin, and $\mathrm{SO}_{2}$ concentrations at Zeppelin and in Ny Ålesund (NA $\mathrm{SO}_{2}$ ) $\left[\mu \mathrm{g} \mathrm{m}^{-3}\right]$ when periods with ship influence were filtered out ("background", bkgr) and for the entire data set (all), for various averaging time periods. Relative increases (incr) over the background periods are given in $\%$.

\begin{tabular}{lrrr|rrr|rrr}
\hline \multirow{2}{*}{$\begin{array}{l}\text { Substance, } \\
\text { years used }\end{array}$} & \multicolumn{3}{c|}{$\begin{array}{c}\text { Summer, daytime only } \\
\text { low wind }\end{array}$} & \multicolumn{2}{c|}{ Summer, daytime only } & \multicolumn{3}{|c}{ Summer } \\
\cline { 2 - 10 } & bkgr & all & incr & bkgr & all & incr & bkgr & all & incr \\
\hline EBC (2003-2005) & 19.9 & 24.7 & $24 \%$ & 16.9 & 19.0 & $12 \%$ & 16.2 & 17.6 & $8 \%$ \\
EBC (2006-2011) & 8.0 & 10.3 & $30 \%$ & 7.0 & 8.6 & $23 \%$ & 7.3 & 8.2 & $11 \%$ \\
$\mathrm{PN}(2003-2010)$ & 199 & 261 & $31 \%$ & 173 & 228 & $32 \%$ & 182 & 215 & $18 \%$ \\
$\mathrm{O}_{3}(2003-2011)$ & 59.4 & 57.7 & $-4 \%$ & 58.9 & 57.4 & $-2 \%$ & 58.7 & 57.6 & $-2 \%$ \\
$\mathrm{SO}_{2}(2003-2011)$ & - & - & - & - & - & - & 55.5 & 64.0 & $15 \%$ \\
$\mathrm{NA}-\mathrm{SO}_{2}(2008-2010)$ & - & - & - & 0.28 & 0.33 & $18 \%$ & 0.20 & 0.24 & $21 \%$ \\
\hline
\end{tabular}

\section{Discussion and conclusions}

In this study we have shown that tourist ships have a substantial influence on measured $\mathrm{SO}_{2}, \mathrm{EBC}, \mathrm{PN} 60$ and $\mathrm{O}_{3}$ concentrations at Ny Ålesund and Zeppelin during summer. When ships with a total of more than 50 passengers cruise in the Kongsfjord, measured daytime mean concentrations of $\mathrm{SO}_{2}$ in Ny Ålesund and EBC and PN60 at Zeppelin show enhancements of $45 \%, 44 \%$ and $72 \%$ over values averaged over periods when ships are not present (results presented in Fig. 4). Even larger enhancements for EBC and PN60 of $72 \%$ and $81 \%$ were found under low-wind conditions, while differences when the entire summer (including nighttime) was considered were slightly lower, $37 \%$ and $58 \%$, respectively. The differences between the two data subsets are largest for the highest measured percentiles, while relatively small differences were found for the median concentrations, indicating that ship plumes carry high pollutant concentrations but are sampled relatively infrequently. In contrast, $\mathrm{O}_{3}$ concentrations were decreased during periods when ships were present, a consequence of titration with NO emissions. Thus, no indication of net $\mathrm{O}_{3}$ formation in the ship plumes was found, but this could still occur further away.

Taking into account the different frequencies of periods with ship or no ship influence, we evaluated the total effect of ship plumes on $\mathrm{SO}_{2}, \mathrm{EBC}$ and PN60 concentrations by calculating the increases in the summer mean concentrations over background conditions without ship influence. These increases were $15 \%, 11 \%$ and $18 \%$, for $\mathrm{SO}_{2}, \mathrm{EBC}$ and PN60, respectively, for summer. Larger increases were found for daytime only periods, and even larger increases for daytime low-wind periods only. This EBC fraction can be compared with the global fraction of $\mathrm{BC}, 2 \%$, which is due to shipping emissions (Lack et al., 2008). The yearly average burden is currently low, however there are some days during summer for which the contribution from ships is significant. However, with respect to the shortwave radiative effects of aerosols (including the albedo effect of the deposition of $\mathrm{BC}$ on the snow), the spring to summer period is particularly important
(Quinn et al., 2008). It can also be expected that summertime $\mathrm{BC}$ deposition is enhanced by a similar factor as the measured atmospheric $\mathrm{BC}$ concentrations, whereas annual total deposition is probably enhanced only marginally by the ship emissions.

The values reported in this paper are only lower estimates for the ship influence on pollutant concentrations. Our relatively simple method of separating the data into periods when ships were present in the fjord and periods when there were no ships does not account for the fact that ship emissions may reside inside the fjord for a longer time and reach the stations outside the periods flagged as influenced by ships in our data sets. Furthermore, some ships may cruise in the fjord for a longer time than assumed in this study, and we know that occasionally ships are not registered at all. This means that even the periods classified as without ships to some extent may be influenced by local ship emissions and thus may not fully represent true background conditions. Furthermore, ships cruising outside the Kongsfjord are not considered in this study, but they may still have some effect on the measured concentrations.

All in all, this leads us to the conclusion that tourist cruise ships have a substantial influence on the measured $\mathrm{SO}_{2}$, $\mathrm{PN60}$, EBC and $\mathrm{O}_{3}$ concentrations (and likely the concentrations of many other compounds) at Ny Ålesund and Zeppelin during summer. This makes it more difficult to compare the measured concentrations with the concentrations simulated by chemistry transport models (e.g., Shindell et al., 2008), which do not correctly include these local emissions. Data analyses can also be affected by the ship influence. For instance, the source region analyses of Hirdman et al. (2010a, b) used the highest and lowest $10 \%$ of the measured concentrations but the former may have been contaminated substantially by ship plumes, probably explaining the lack of a clear source region signal in summer. Nevertheless, Zeppelin remains as one of the most valuable Arctic observatories, since most other stations face even more severe local contamination problems. Furthermore, a careful screening of the Zeppelin data allows excluding periods influenced by ship 
emissions. We estimate that during the years 2002 to 2011, data were contaminated by local ship emissions for only during around $60 \mathrm{~h}$ per year. However, it is difficult to screen monitoring data with coarse temporal resolution (e.g., filter samples), since most of the samples will contain some influence from ship plumes.

This study has shown that ships cruising in the Arctic can already have a substantial influence on the pollutant concentrations in pristine areas of the Arctic, at least on a local scale. If Arctic shipping in summer increases as predicted over the next few decades (e.g., Corbett et al., 2010) the entire Arctic may be affected by ship emissions. Thus, the influence currently seen at Ny Ålesund and Zeppelin may be a harbinger of a much more pronounced pan-Arctic ship pollution influence in the future. More stringent regulations on ship emissions could help to reduce this impact.

Acknowledgements. The research leading to these results has received funding from the European Union Seventh Framework Programme (FP7/2007-2013) under grant agreement no. 282688 - ECLIPSE, and the Norwegian Research Council as part of the CLIMSLIP project, and was supported by the Arctic Monitoring and Assessment Programme (AMAP). Involved researchers participate in the Nordic Center of Excellence CRAICC funded by Nordforsk. We thank the research advisor Hallvar Gisnås at Kings Bay AS for supplying the harbor log and Rita Våler for processing the Kings Bay data. We thank KLIF for funding the ozone and $\mathrm{SO}_{2}$ measurements at Zeppelin, Johan Ström and $\mathrm{H}$. C. Hansson for the AAC and PNSD measurements, and Dorothea Schulze and Vigdis Lonar Barth for performing the $\mathrm{SO}_{2}$ measurements in $\mathrm{Ny}$ Alesund. We thank the two reviewers for their valuable comments on this manuscript.

Edited by: M. Boy

\section{References}

Aas, W., Hanssen, J. E., and Schaug, J.: Field intercomparison of main components in air in EMEP, Water Air Soil Poll., 15677230, doi:10.1007/s11267-006-9085-7, 2007.

Bond, T. and Bergstrom, R.: Light absorption by carbonaceous particles: An investigative review, Aerosol Sci. Technol., 40, 27-67, 2006.

Bond, T. C., Anderson, T. L., and Campbell, D.: Calibration and intercomparison of filter-based measurements of visible light absorption by aerosols, Aerosol Sci. Tech., 30, 582-600, 1999.

Corbett, J. J., Winebrake, J. J., Green, E. H., Kasibhatla, P., Eyring, V., and Lauer, A.: Mortality from ship emissions: A global assessment, Environ. Sci. Technol., 41, 8512-8518, doi:10.1021/es071686z, 2007.

Corbett, J. J., Lack, D. A., Winebrake, J. J., Harder, S., Silberman, J. A., and Gold, M.: Arctic shipping emissions inventories and future scenarios, Atmos. Chem. Phys., 10, 9689-9704, doi:10.5194/acp-10-9689-2010, 2010.

Dalsøren, S. B., Ø. Endresen, I. S. A. Isaksen, G. Gravir, and Sørgård, E.: Environmental impacts of the expected increase in sea transportation, with a particular focus on oil and gas scenarios for Norway and northwest Russia, J. Geophys. Res., 112, D02310, doi:10.1029/2005JD006927, 2007.

Dalsøren, S. B., Samset, B. H., Myhre, G., Corbett, J. J., Minjares, R., Lack, D., and Fuglestvedt, J. S.: Environmental impacts of shipping in 2030 with a particular focus on the Arctic region, Atmos. Chem. Phys., 13, 1941-1955, doi:10.5194/acp-13-19412013, 2013.

Di Liberto, L., Angelini, F., Pietroni, I., Cairo, F., Di Donfrancesco, G., Viola, A., Argentini, S., Fierli, F., Gobbi, G., Maturilli, M., Neuber, R., and Snels, M.: Estimate of the Arctic Convective boundary layer height from lidar observations: A case study, Adv. Meteorol., 2012, 851927, doi:10.1155/2012/851927, 2012.

Eleftheriadis, K., Vratolis, S., and Nyeki, S.: Aerosol black carbon in the European Arctic: Measurements at Zeppelin station, Ny-Alesund, Svalbard from 1998-2007, Geophys. Res. Lett., 36, L02809, doi:10.1029/2008g1035741, 2009.

EMEP/CCC: Manual for sampling and chemical analysis, Norwegian Institute for Air Research, Kjeller, EMEP/CCC Report 1/95 (Last rev. 2001), http://tarantula.nilu.no/projects/ccc/, 2001.

Graf, H.-F., Shirsat, S. V., Oppenheimer, C., Jarvis, M. J., Podzun, R., and Jacob, D.: Continental scale Antarctic deposition of sulphur and black carbon from anthropogenic and volcanic sources, Atmos. Chem. Phys., 10, 2457-2465, doi:10.5194/acp-10-24572010, 2010.

Hagen, D., Vistad, O. I., Eide, N. E., Flyen, A. C., and Fangel, K.: Managing visitor sites in Svalbard: from a precautionary approach towards knowledge-based management, Polar Res., 31, 18432, doi:10.3402/polar.v31i0.18432, 2012.

Hirdman, D., Sodemann, H., Eckhardt, S., Burkhart, J. F., Jefferson, A., Mefford, T., Quinn, P. K., Sharma, S., Ström, J., and Stohl, A.: Source identification of short-lived air pollutants in the Arctic using statistical analysis of measurement data and particle dispersion model output, Atmos. Chem. Phys., 10, 669-693, doi:10.5194/acp-10-669-2010, 2010a.

Hirdman, D., Burkhart, J. F., Sodemann, H., Eckhardt, S., Jefferson, A., Quinn, P. K., Sharma, S., Ström, J., and Stohl, A.: Longterm trends of black carbon and sulphate aerosol in the Arctic: changes in atmospheric transport and source region emissions, Atmos. Chem. Phys., 10, 9351-9368, doi:10.5194/acp-10-93512010, 2010b.

Jokinen, V. and Makela, J. M.: Closed-loop arrangement with critical orifice for DMA sheath excess flow system, J. Aerosol. Sci., 28, 643-648, 1997.

Knutson, E. O. and Whitby, K. T.: Anomalous unipolar diffusion charging of plystyrene aerosols, J. Colloid Interf. Sci., 53, 493 495, doi:10.1016/0021-9797(75)90067-3, 1975.

Lack, D. A. and Corbett, J. J.: Black carbon from ships: a review of the effects of ship speed, fuel quality and exhaust gas scrubbing, Atmos. Chem. Phys., 12, 3985-4000, doi:10.5194/acp-12-39852012, 2012.

Lack, D., Lerner, B., Granier, C., Baynard, T., Lovejoy, E., Massoli, P., Ravishankara, A. R., and Williams, E.: Light absorbing carbon emissions from commercial shipping, Geophys. Res. Lett., 35, L13815, doi:10.1029/2008g1033906, 2008.

Ødemark, K., Dalsøren, S. B., Samset, B. H., Berntsen, T. K., Fuglestvedt, J. S., and Myhre, G.: Short-lived climate forcers from current shipping and petroleum activities in the Arctic, Atmos. Chem. Phys., 12, 1979-1993, doi:10.5194/acp-12-1979-2012, 
2012.

Peters, G. P., Nilssen, T. B., Lindholt, L., Eide, M. S., Glomsrød, S., Eide, L. I., and Fuglestvedt, J. S.: Future emissions from shipping and petroleum activities in the Arctic, Atmos. Chem. Phys., 11, 5305-5320, doi:10.5194/acp-11-5305-2011, 2011.

Petzold, A., Hasselbach, J., Lauer, P., Baumann, R., Franke, K., Gurk, C., Schlager, H., and Weingartner, E.: Experimental studies on particle emissions from cruising ship, their characteristic properties, transformation and atmospheric lifetime in the marine boundary layer, Atmos. Chem. Phys., 8, 2387-2403, doi:10.5194/acp-8-2387-2008, 2008.

Quinn, P. K., Bates, T. S., Baum, E., Doubleday, N., Fiore, A. M., Flanner, M., Fridlind, A., Garrett, T. J., Koch, D., Menon, S., Shindell, D., Stohl, A., and Warren, S. G.: Short-lived pollutants in the Arctic: their climate impact and possible mitigation strategies, Atmos. Chem. Phys., 8, 1723-1735, doi:10.5194/acp8-1723-2008, 2008.

Shindell, D. T., Chin, M., Dentener, F., Doherty, R. M., Faluvegi, G., Fiore, A. M., Hess, P., Koch, D. M., MacKenzie, I. A., Sanderson, M. G., Schultz, M. G., Schulz, M., Stevenson, D. S., Teich, H., Textor, C., Wild, O., Bergmann, D. J., Bey, I., Bian, H., Cuvelier, C., Duncan, B. N., Folberth, G., Horowitz, L. W., Jonson, J., Kaminski, J. W., Marmer, E., Park, R., Pringle, K. J., Schroeder, S., Szopa, S., Takemura, T., Zeng, G., Keating, T. J., and Zuber, A.: A multi-model assessment of pollution transport to the Arctic, Atmos. Chem. Phys., 8, 5353-5372, doi:10.5194/acp-85353-2008, 2008.

Stohl, A.: Characteristics of atmospheric transport into the Arctic troposphere, J. Geophys. Res., 111, D11306, doi:10.1029/2005JD006888, 2006.
Strom, J., Umegard, J., Torseth, K., Tunved, P., Hansson, H. C., Holmen, K., Wismann, V., Herber, A., and Konig-Langlo, G.: One year of particle size distribution and aerosol chemical composition measurements at the Zeppelin Station, Svalbard, March 2000-March 2001, Phys. Chem. Earth, 28, 1181-1190, doi:10.1016/j.pce.2003.08.058, 2003.

Tunved, P., Ström, J., and Krejci, R.: Arctic aerosol life cycle: linking aerosol size distributions observed between 2000 and 2010 with air mass transport and precipitation at Zeppelin station, Ny-Ålesund, Svalbard, Atmos. Chem. Phys., 13, 3643-3660, doi:10.5194/acp-13-3643-2013, 2013.

Vestreng, V., Kallenborn, R., and Økstad, E.: Climate influencing emissions, scenarios and mitigation options at Svalbard, Klimaog forurensningsdirektoratet, Report TA-2552/2009, Oslo, 2009.

Vihma, T., Kilpeläinen, T., Manninen, M., Sjöblom, A., Jakobson, E., Palo, T., Jaagus, J., and Maturilli, M.: Characteristics of temperature and humidity inversions and low-level jets over Svalbard Fjords in Spring, Adv. Meteorol., 2011, 486807, doi:10.1155/2011/486807, 2011.

Weinbruch, S., Wiesemann, D., Ebert, M., Schutze, K., Kallenborn, R., and Strom, J.: Chemical composition and sources of aerosol particles at Zeppelin Mountain (Ny Alesund, Svalbard): An electron microscopy study, Atmos. Environ., 49, 142-150, doi:10.1016/j.atmosenv.2011.12.008, 2012.

Xie, Z., Blum, J. D., Utsunomiya, S., Ewing, R. C., Wang, X., and Sun, L.: Summertime carbonaceous aerosols collected in the marine boundary layer of the Arctic Ocean, J. Geophys. Res., 112, D02306, doi:10.1029/2006JD007247, 2007. 